\title{
Study on Countermeasures to Promote the Development of Social Organizations
}

\author{
Yingxia Liu \\ College of Economics and Management, Dalian University,Dalian, China \\ lyx111505@sina.com
}

\begin{abstract}
Keywords: Social organization; Social development; Social worker; Social governance; Social
\end{abstract} resource

\begin{abstract}
In the current social governance system, the development of social organizations is still in its infancy with the problems of small amount, insufficient development, unclear function orientation of social role, low contribution to economic development, imperfect organization management system, requiring related departments to increase support for the development of social organizations, mobilize social forces to participate in more social organizations and work, strengthen the training and regulation of personnel engaged in social organization work so as to boost the development of the whole situation with community as the important grasp.
\end{abstract}

\section{Introduction}

Social organizations have been developing steadily in recent years, scattered everywhere in both urban and rural areas, involving various fields of social life, becoming the bridge and bond connecting party and the government with the mass [1], and the main force of the economic and social development. It's the demand of China's social change to promote the development of social organizations; however, the development of social organizations is in the initial stage both in theory and practice. To varying degrees, there are problems in the social organization development of each city, requiring to further raise awareness of studying the development countermeasures.

\section{The Implication, Feature and Classification of Social Organizations}

The Implication of Social Organization. From sociological perspective, the broad social organization refers to the existing forms of community or group for human activities in the society, such as family, government, army, clan, interest groups, college communities, QQ clubs, We chat groups, etc. In the narrow sense, social organization is the various social groups consciously organized together for the united actions in order to achieve specific goals, including businesses, schools, military, all sorts of accounting firms, literary federation, all sorts of secret societies, etc.

The Feature of Social Organization. The two most obvious features of social organization:

Voluntary and non-governmental. Comparing with the formal organization, these institutions are organized actively and voluntarily by the participants rather than organized by the government or the extension of the government's political functions, but the service provided by these institutions can be purchased by the government in order to supplement the governmental functions.

Nonprofit. Social organization is nonprofit, which does not mean that it cannot be engaged in business activities, but it can conduct a variety of professional business. However, the business income cannot be distributed to its members as some kind of residual income or profit, but only can be used as the expenditure of organization activities so as to better maintain the organization operation. The assets of organization shall not be transformed into personal property in any form; the asset cannot be withdrawn if members put the assets into the nonprofit organizations, even if the organization disappears, when the relevant funds or assets shall be delivered to other organizations or 
government with similar nature under the organization of the relevant departments.

The Classification of Social Organization. There are a lot of the classifications of social organization; combined with the actual development of China, the following classifications are common, as shown in table 1.

Table 1 The Classification Criterion and Description of Social Organization

\begin{tabular}{l|l}
\hline Classification criterion & \multicolumn{1}{|c}{ Classification description } \\
\hline Scale & Small-sized, middle-sized large-scale giant \\
\hline $\begin{array}{l}\text { Relational properties of } \\
\text { organization members }\end{array}$ & Formal organization, informal organization \\
\hline $\begin{array}{l}\text { Function and aim of } \\
\text { organization }\end{array}$ & $\begin{array}{l}\text { Economic organization, political organization, } \\
\text { cultural, educational and research organization, } \\
\text { mass organization and religious organization }\end{array}$ \\
\hline Organization nature & $\begin{array}{l}\text { Social organization, private non-enterprise units, } \\
\text { foundation }\end{array}$ \\
\hline Activity field & $\begin{array}{l}\text { Economy, scientific research, social undertaking, } \\
\text { charity, general works }\end{array}$ \\
\hline
\end{tabular}

In this paper, social organization is classified according to organization nature into social organization, private non-enterprise units and foundation, of which the social organization can be divided into: industry associations (including all sorts of chamber of commerce or industry association), academic communities, professional organizations and united community.

The Development and Functional Orientation of Social Organization in China. With the support of national policy, the active participation and efforts of governments and the masses, the current social organization achieve a rapid growth. By the end of 2013, nearly 547,000 social organizations register around the country [2], in addition, there are lots of unregistered "grass-roots organization" and more than 400 foreign social organizations in China. It's necessary to locate the social organization for the development so as to strengthen the guidance and supervision.

To Assist the Government for the Social Governance. In the current social governance structure, social construction has been raised to an important position as the basic content of five-in-one [3]. However, it is difficult to give a full play for many social and economic affairs by administrative means of government, but social organization can find big development space. Social organization can help resolve and adjust the social problems in the lives of the people such as stray dogs, weddings, funerals, petition, etc.[4]

To Make up the Deficiency of Social Governance [5]. In the era of planned economy, the government mainly achieved the overall management and control of the society based on the unit; however, with the transformation of ways from social management to social governance, the identity change of a large number of social members brings challenges for the government social governance; the implementation of social affairs from top to bottom is frustrated, but social organization can make up the deficiency because the characteristic of the universality and diversity can infiltrate into every corner of the management, and its openness and integrity can make it more close to the life of the people for solving practical problems.

To Promote the Integration of Social Resources. Social organization sometimes has better effect on integration of social resources than administrative order as the time and spirit of government are limited for all aspects of the social governance, which is difficult to give attention to the needs and interests of all people. The Third Plenary Session of the 18th meeting of CPC also repeatedly emphasized the positive role of social organizations in the aspects of politics, economy, culture, society and party construction as well as the integration of social resources [6] and arousing the 
enthusiasm of citizens for social governance.

To Promote Social Harmony. Social organization has the function of demonstration and solving problems in the aspects of providing public services, enhancing the social vitality and promoting the integration of social power. Meanwhile, due to the advantages of coming from the masses, rooting in the masses, extensive ties with the masses, and direct services for the masses[7], social organizations win more understanding and trust so as to help the government ease a series of social contradictions; the "buffer zone" built between the government and the citizen eases the antagonism, reduces the social conflicts and promotes social harmony.

\section{The Current Situation and Main Problems Existed in Social Organization}

Small Amount and Insufficient Development. From the perspective of the development situation of current global social organizations, there are as many as millions of social organizations and more than 50 various international organizations [8]. The proportion of social organizations in developed countries is more than 50 per 10 thousand people, and more than 10 per 10 thousand people in developing countries; the proportion is 2.7 per 10 thousand people in China, which is hard to meet the need of diversification of social and economic development; various social forces have the potential to be aroused.

The Positioning of Social Role and Function is not Clear. The administrative color of social organization management is more distinctive; although the call for "de-administration" has been very high, the strength of movement is insufficient. Due to the state of indistinguishable political and social organizations, self-discipline of legal person in social organizations is not high, and the participation opportunities of the masses are fewer, which makes it not typical.

The Social Organization Lacking of Capacity. As a kind of nonprofit and social organization, social organization is independent of the system of party and government and the enterprise and public institution. In the process of social development, its sever function is weak, such as provision of social welfare service, employment settlement for unemployed people and household service[9].

Imperfect Management System of Social Organization. Now, the social organization is still the emerging forms of organizational structure, so the team-building, design of organizational structure are all at primary level. There will inevitably be some problems such as staff shortage, capital shortage, and ill operation due to no requirements of modern management mode and management system. For example, community is one kind of social organization form of the fastest growing in recent years, but too many problems occur due to the unsound management system, such as small number of community workers, comparatively low personnel quality, lack of performance appraisal system, etc. The most frustrating part is the function check, and there is no specification document for the positioning of community function. The grassroots community with around 10 people has more than 100 pieces of daily work.

\section{Relevant Counter Measures to Promote the Development of Social Organization}

Increase the Intensity of Development and Call on More Social Forces for Participation. Increase the intensity of development and call on more social forces to participate in social organizations, such as the founding of volunteer organization. The enthusiasm participating activities of volunteers community and station in colleges and universities is higher, but the development of the organization is affected due to no chance. It's suggested that the central station of city volunteers in some colleges and universities can often call up these organizations for activities, actively encourage the expansion of organization, and try to integrate more power.

In addition, strengthen the hatch base construction of social organization. Formulate specific hatch policy and benchmark of hatch effect. The operation effect of existing hatch base should be known, 
and the degree of citizen satisfaction and contribution to the society should also be grasped.

Offer Various Protections and Encourage the Development of Social Organization. The development of social organizations will be restricted by their limited experience on the one hand; on the other hand, it will be restricted by the imperfect system, policy guarantee, operation mechanism as well as the environment. Therefore, relevant departments should be organized together to formulate relevant policies and measures to encourage the development of social organization, and ensure the implementation of fairness and justice rather than empty talk.

Strengthen Training and Supervision of the Workers in Social Organization. The workers in various social organizations are always varied; not only in terms of age and education background but also more gaps in experience, so more trainings of these workers are urgent. Under the premise of higher quality of the workers in social community, the supervision and evaluation efforts of community work and social organization work should be strengthened [10], and the annual inspection system of social organizations should be completed. The appraisal of social organization from a third-party professional appraisal agency will make the management of social organizations more specialized and standardized.

In recent years, some cities have continuously carried out the training to the community leaders, community financial personnel, social organization forum, head of the private non-enterprise units, and registration and management personnel of district, city and county, and have achieved a better result. Relevant departments of the city government have begun to attach importance to the external support and regulation of the development of social organizations, but these trainings and regulations are obviously insufficient comparing with the increasing number of social organizations. Therefore, it is necessary to increase inputs, raise awareness, simplify various registration procedures, improve the personnel quality and regulatory measures.

Take the Development of Community Social Organization as the Grasp, and Boost the Development of Social Organizations in the Whole City. Community is the basic unit of the society, and plays an important role in the development of the city [11]. The development of community has shown its unique advantages in recent years, and the social organization established relying on the community should also be taken seriously. Some cities have introduced relevant regulations encouraging the development of community social organizations, such as documents <guidance of community social organizations in $* * *$ city>, <management measures for the record of community social organization>, etc. The favorable conditions such as the specification for the development of community social organizations, more fund support to community social organizations from district, city and county, will speed up the development of community social organizations. At the same time, the city finance will also allocate special funds to support development of social organization, launch a variety of activities, and enhance civil sense of belonging and satisfaction in the community. It's the innovative concept to the community work and social management work centering on the development of community social organization and driving the development of social organization in the whole city.

\section{Conclusion}

The appeal of vigorously developing social organization was put forward in recent years, but it's growing rapidly. The analysis and study should be conducted synthesizing the conditions of the country, the city, the economic and social progress, trend of transformation and development of social organization. Draw lessons from the practical experience of other countries, innovate working ideas and study the construction of effective regulations and policies so as to establish modern social organization management system and mechanism. 


\section{Acknowledgements}

1. Study on aging and the social endowment service system of LiaoNing. No: 2014lslktzishx-03, Liaoning Social science union, 2014.

2. Study on the advance of community service marketization model,No:dlskzd2014004,Dalian Social science union, 2014.

\section{Literature References}

[1] Q. Zheng: Chinese Cadres Tribute,Vol.(2015).No.2.p.73, In Chinese.

[2] H.Liao:Institutions reform in China, Vol.(2014).No.12.p.32. In Chinese.

[3] M.S. Zhang :Learn, Vol.(2015).No.1.p.22. In Chinese.

[4] X.L. Zeng, J.J.Pan: Seek, Vol.(2013).No.4. In Chinese.

[5] L.F. Chen: Fujian forum, Vol.(2014).No.11. In Chinese.

[6] Y.M. Fan: Journal of the Party school, Taiyuan Municipal Committee, CCP, Vol.(2015).No.1. In Chinese.

[7] J.Z. Xia: On the development of community social organizations: experiences from China and Abroad(China Social Press.China,2011. pp.182) .In Chinese.

[8] Information on http://www.doc88.com/p-9018132067049.html. In Chinese.

[9][10] C.D. Zhang Study on the classification and management of social organization (Ph.D.,Hunan University, China 2012), p.26, p.27. In Chinese.

[11] R.S.Jiao, W.J. Chen: Scientific socialism, Vol.(2015).No.2.In Chinese.

[12]Z.G.Tang: Social organizations in China, .(2015).No.1 .In Chinese. 